\title{
PENENTUAN FORUM YANG BERWENANG DAN MODEL PENYELESAIAN SENGKETA TRANSAKSI BISNIS INTERNASIONAL MENGGUNAKAN E-COMMERCE: STUDI KEPASTIAN HUKUM DALAM PEMBANGUNAN EKONOMI NASIONAL
}

\author{
(The Determination of Authorized Forum and Dispute Resolution Models of International Business \\ Transaction that Using E-Commerce: Legal Certainty Studies in National Economic Development)
}

\author{
M. Alvi Syahrin \\ Pusat Penelitian dan Pengabdian Masyarakat Politeknik Imigrasi \\ Jl. Raya Gandul No. 4, Cinere, Depok, Jawa Barat, Indonesia \\ Email: ma.syahrin@gmail.com
}

Naskah diterima: 4 Juni 2018; revisi: 4 Juli 2018; disetujui: 2 Agustus 2018

\begin{abstract}
Abstrak
Keberadaan e-commerce telah mengubah tatanan transaksi bisnis di Indonesia. E-commerce lahir atas tuntutan masyarakat terhadap pelayanan yang serba cepat, mudah dan praktis melalui internet. Namun dalam praktiknya, sengketa e-commerce kerap kali muncul dikarenakan perbedaan kepentingan di antara para pihak. Sengketa ini melibatkan lintas negara yang menimbulkan permasalahan forum mana yang berwenang mengadili sengketa tersebut. Dengan menggunakan metode penelitian yuridis normatif hasil penelitian menunjukan bahwa Forum yang berwenang dalam penyelesaian sengketa transaksi bisnis internasional yang menggunakan e-commerce adalah forum yang dipilih atas dasar kesepakatan para pihak (choice of forum) dalam kontrak elektronik internasional yang mereka buat. Namun, bila para pihak tidak menentukan pilihan forum dalam kontrak elektronik internasional yang dibuatnya, maka mengacu pada forum dari negara penjual atas dasar ketentuan yang termaktub dalam asas-asas Hukum Perdata Internasional. Hal ini dikarenakan, penjual merupakan pihak yang memiliki prestasi paling karakteristik dibanding pihak lainnya. Penentuan tersebut didasarkan atas Substansial Connection Theory sebagaimana yang dikemukakan dalam Principle 2.1 bagian (2) dari PTCP (tentang Jurisdiction over Parties). Adapun terkait dengan model penyelesaian sengketa tersebut dimungkinkan untuk digunakannya dua mekanisme, yaitu jalur litigasi dan non litigasi. Mekanisme litigasi berupa jalur penyelesaian sengketa melalui pengadilan. Sedangkan non litigasi dapat dilakukan dengan jalur penyelesaian sengketa melalui arbtirase, negosiasi, mediasi, dan konsiliasi.
\end{abstract}

Kata Kunci: forum berwenang, penyelesaian sengketa, e-commerce

\begin{abstract}
The existence of e-commerce has changed the order of business transactions in Indonesia. E-commerce was born on the demands of society to the fast-paced, easy and practical service via the internet. But in practice, e-commerce disputes often arise because of differences in interests between the parties. These disputes involve cross-border countries raising the issue of which authorized forums are to adjudicate the dispute. The authorized forums to deal with the settlement of fraudulent international business transactions using e-commerce are provided for in Article 18 paragraph (4) and (5) of Law of the Republic Indonesia Number 11 of 2008 concerning Information and Electronic Transactions. Based on the results of the research: (i) Authorized forums to resolve disputes of international business transactions using e-commerce are selected forums on the basis of the choice of forums in the international electronic contracts they make. However, if the parties do not specify the choice of forum in the international electronic contract, it makes is to refer to the forum of the seller state on the basis of the provisions set forth in the Principles of the International Civil Code. This is because, the seller is the party that has the most characteristic achievement than the other party. The determination is based on Substantial Connection Theory as set forth in Principle 2.1 part (2) of PTCP (regarding Jurisdiction over Parties). (ii) As for the dispute resolution model it is possible to use two mechanisms, namely litigation and non litigation lanes. The litigation mechanism is a dispute settlement through the courts. While non litigation can be done with the path of dispute settlement through arbtirase, negotiation, mediation, and consiliation.
\end{abstract}

Keywords: authorized forum, dispute resolution, e-commerce 


\section{A. Pendahuluan}

Perkembangan teknologi informasi ${ }^{1}$ pada awal abad dua puluh satu ini telah menyebabkan informasi dapat bergerak dengan cepat. Informasi mengalir dari suatu lokasi ke lokasi lain tanpa dibatasi oleh jarak di antara lokasi-lokasi itu sendiri. ${ }^{2}$ Perkembangan teknologi informasi dan komunikasi semacam ini telah pula menyebabkan hubungan dunia menjadi tanpa batas (borderless) ${ }^{3}$ dan menyebabkan perubahan sosial, ekonomi, dan budaya secara signifikan berlangsung sedemikian cepat. ${ }^{4}$ Tidak hanya itu, pemanfaatannya pun telah semakin meluas sehingga memasuki hampir semua segi kehidupan. ${ }^{5}$

Salah satu produk inovasi teknologi telekomunikasi adalah internet ${ }^{6}$ (interconnection networking), yaitu koneksi antar jaringan komputer. Internet yang merupakan implementasi dari Transmission Control Protocol atau Internet Protocol (TCP atau IP) telah memberikan kemudahan dalam berkomunikasi secara global tanpa batasan geografis antar negara. Komunikasi tersebut dapat meliputi komunikasi antar pribadi dengan menggunakan elektronik mail (e-mail) atau tayangan informasi bebas baca yang disebut sebagai World Wide Web atau yang disingkat WWW atau lebih singkat disebut Web. ${ }^{7}$

Dengan meningkatnya penggunaan internet, khususnya di Indonesia maka secara tidak langsung berdampak besar bagi perkembangan dunia bisnis. Sebagaimana diketahui bahwa dewasa ini aplikasi internet telah memasuki berbagai segmen aktivitas manusia baik dalam sektor politik sosial, budaya, maupun ekonomi dan bisnis. Dalam bidang perdagangan, internet mulai banyak dimanfaatkan sebagai media aktvitas bisnis terutama karena kontribusinya terhadap efisiensi. ${ }^{8}$ Aktivitas perdagangan melalui media internet ini terkenal dengan sebutan electronic commerce (e-commerce). ${ }^{9}$ E-commerce tersebut terbagi atas dua segmen,

1 Menurut Ade Maman Suherman, teknologi informasi dikategorikan sebagai revolusi industri tahap ketiga (tahun 1950-sekarang), setelah sebelumnya revolusi industri pertama (tahun 1760-1840) dan revolusi industri kedua (tahun 1840-1950). Pada masa revolusi industri tahap ketiga ini, semua tingkatan masyarakat industri sangat bergantung pada kegiatan ekonomi yang berbasiskan informasi, dimana peranan teknologi komputer memiliki peranan yang sangat menentukan, seperti halnya semakin banyaknya praktik bisnis yang sangat bergantung pada IT (Information Technology), khususnya komputer. Lihat, Ade Maman Suherman, Aspek Hukum dalam Ekonomi Global, (Jakarta: Ghalia Indonesia, 2001), hlm. 178.

2 Ade Maman Suherman dalam Yahya Ahmad Zein, Kontrak Elektronik dan Penyelesaian Sengketa Bisnis E-Commerce: Dalam Transaksi Nasional dan Internasional, (Bandung: Mandar Maju, 2009), hlm. 1.

3 Baca, Ahmad M. Ramli, Cet-2, Cyberlaw dan HAKI dalam Sistem Hukum Indonesia, (Bandung: PT. Refika Aditama, 2006), hlm. 1.

4 Periksa, Indonesia, Undang-Undang tentang Informasi dan Transaksi Elektronik, UU No. 11 Tahun 2008, LN Tahun 2008 Nomor 58, TLN Nomor 4843 (selanjutnya disebut UU ITE), Penjelasan.

$5 \quad$ M. Arsyad Sanusi, Hukum Teknologi Informasi, Cet-3, (Tim Kemas Buku, 2005), hlm. 1.

6 Secara singkat, internet adalah sebuah alat penyebaran informasi secara global, sebuah mekanisme penyebaran informasi dan sebuah media untuk berkolaborasi dan berinteraksi antar individu dengan menggunakan komputer tanpa terhalang batas geografis. Periksa, Riyeke Ustadianto, Framework E-Commerce, Cet-1, (Yogyakarta: Penerbit Andi, 2001), hlm. 1; Sementara itu, SP Hariningsih, mengemukakan bahwa internet adalah media komunikasi alternatif yang dalam batas-batas pemakaian tertentu dapat digunakan untuk menggantikan media komunikasi tradisionil, seperti pos, telepon, dan fax. Baca, SP Hariningsih, Teknologi Informasi, (Jakarta: Graha Ilmu, 2005), hlm. 125.

7 Yahya Ahmad Zein, Op. cit., hlm. 3.

8 Indonesia Corrupton Watch (ICW) merilis temuan barunya bahwa pengadaan barang dan jasa dengan cara online (internet) lebih hemat biaya 30\% dibanding manual. Dimuat dalam Running Text pada acara Metro Hari Ini pada hari Jum'at, 28 Mei 2010, Pukul 17.25 WIB.

9 Baca, Mieke Komar Kantaatmadja et. al, Cyberlaw: Suatu Pengantar (Seri Dasar Hukum Ekonomi), (Bandung: ELIPS II, 2002), hlm. 28. 
yaitu business to business e-commerce

Sistem perdagangan dengan memanfaat(perdagangan antar pelaku usaha) dan business to consumer e-commerce (perdagangan antar pelaku usaha dengan konsumen). ${ }^{10}$

UNCITRAL Model Law on Electronic Commerce memberikan definisi terkait dengan e-commerce. ${ }^{11}$ Secara singkat dalam Pasal 1 dan

2, e-commerce didefinisikan sebagai:

"setiap aktivitas perdagangan yang dilaksanakan dengan cara melakukan pertukaran informasi yang diberikan, diterima atau disimpan melalui jasa elektronik, optik atau alat serupa lainnya termasuk, tetapi tidak terbatas pada EDI, e-mail, telegram, telex, atau telekopi". ${ }^{12}$

kan sarana internet, yang selanjutnya disebut e-commerce telah mengubah tatanan transaksi bisnis di Indonesia. Selain disebabkan oleh adanya perkembangan teknologi informasi, ecommerce lahir atas tuntutan masyarakat terhadap pelayanan yang serba cepat, mudah dan praktis melalui internet. Sehingga masyarakat memiliki ruang gerak yang cukup luas dalam memilih produk (barang dan jasa) yang akan dipergunakan tentunya dengan berbagai kualitas dan kuantitas sesuai dengan yang diinginkan. ${ }^{13}$

Mekanisme kerja pasar elektronik dalam e-commerce ini dapat dilihat dalam gambar di bawah ini. ${ }^{14}$

\section{Bagan 1. Mekanisme Kerja E-Commerce}

\begin{tabular}{|c|c|c|c|}
\hline $\begin{array}{l}\text { 1. Pembeli } \\
\text { mengakses } \\
\text { internet dan } \\
\text { masuk ke } \\
\text { pasar } \\
\text { elektronik }\end{array}$ & $\begin{array}{l}\text { 2. Pembeli } \\
\text { mencari } \\
\text { produk yang } \\
\text { diinginkan }\end{array}$ & $\begin{array}{l}\text { 3. Pembeli } \\
\text { memilih } \\
\text { produk yang } \\
\text { dikehendaki }\end{array}$ & $\begin{array}{l}\text { 5. Order } \\
\text { pembelian } \\
\text { dikirim ke } \\
\text { penjual }\end{array}$ \\
\hline $\begin{array}{l}\text { 8. Informasi } \\
\text { pembayaran } \\
\text { dikirim ke } \\
\text { Bank }\end{array}$ & $\begin{array}{l}\text { 7. Pembeli } \\
\text { membayar } \\
\text { produk yang } \\
\text { dipesannya }\end{array}$ & $\begin{array}{l}\text { 6. Penjual } \\
\text { konfirmasi } \\
\text { pesanan }\end{array}$ & $\begin{array}{l}\text { 4. Pembeli } \\
\text { memesan } \\
\text { produk yang } \\
\text { dikehendaki }\end{array}$ \\
\hline $\begin{array}{l}\text { 12. Produk } \\
\text { diterima }\end{array}$ & $\begin{array}{l}\text { 9. Permohonan } \\
\text { kredit oleh } \\
\text { pembeli } \\
\text { diverivikasi }\end{array}$ & $\begin{array}{l}10 . \\
\text { Permohonan } \\
\text { kredit oleh } \\
\text { pembeli } \\
\text { disetujui }\end{array}$ & $\begin{array}{l}\text { 11. Produk } \\
\text { dikirim }\end{array}$ \\
\hline
\end{tabular}

10 Yahya Ahmad Zein, Loc. cit; Lihat juga Didik M. Arief Mansur dan Elisatiris Gultom, Op. cit, hlm. 150-152.

11 Dari beberapa survei yang dilakukan, mengindikasikan bahwa terdapat perbedaan pendapat antara para praktisi dan para peneliti di dalam memandang e-commerce. Kalangan praktisi cenderung memandang e-commerce dalam arti sempit, yaitu hanya sebagai proses jual beli barang yang dilakukan melalui internet. Sebaliknya, kebanyakan peneliti lebih cenderung memandang e-commerce dalam arti luas, yaitu e-commerce dimaknai lebih daripada sekedar jual beli barang melalui internet, tetapi mencakup pula berbagai aktifitas pra jual beli dan pasca jual beli yang dilakukan untuk memfasilitasi fokus perusahaan pada konsumen. Lihat, M. Arsyad Sanusi, Hukum Teknologi Informasi, (Jakarta: Tim KemasBuku, 2005), hlm. 135.

12 Niniek Suparni, Cyberspace: Problematika dan Aspek Pengaturannya, (Jakarta: Penerbit Sinar Grafika, 2009 ), hlm. 32.

13 Didik M. Arief Mansur dan Elisatiris Gultom, Cyber Law: Aspek Hukum Teknologi Informasi, Cet-2, (Bandung: PT. Refika Aditama), hlm. 144.

14 Ibid., hlm. 152. 
Mekanisme di atas dikenal juga sebagai transkasi online order di pasar elektronik. Transaksi online order merupakan transaksi bisnis dimana pemesanan barang tersebut dilakukan melalui internet.

Pertumbuhan e-commerce dan marketplace di Indonesia saat ini terus meningkat pesat. Hal tersebut didasarkan pada data yang dirilis oleh ilmu One Data hingga Tahun 2017. Menurut mereka, dari sepuluh peringat teratas, terdapat empat e-commerce dan enam marketplace yang mendominasi kegiatan bisnis digital. Lazada memimpin seluruh e-commerce dengan jumlah 21,2 juta unique audiens. Sedangkan, Tokopedia memimpin martketplace dengan 14,4 juta. Urutan kesepuluh peringkat teratas tersebut antara lain Lazada, Blibli, Tokopedia,
Elevania, Matahari Mall, Shopee, Bukalapak, Zalora, Qoo10, dan Blanja. ${ }^{15}$

Lima e-commerce dengan jumlah unique audiens terbanyak mengalami rata-rata pertumbuhan sebesar 97 persen. Nilai pertumbuhan tertinggi dipegang Matahari Mall, yakni sebesar 201 persen. Disusul JD.id sebesar 135 persen dan Blibli dengan jumlah pertumbuhan 107 persen. ${ }^{16}$

Sedangkan, rata-rata pertumbuhan lima marketplace dengan unique audiens terbanyak mencapai angka 289 persen. Pendatang baru, Shopee mengalami pertumbuhan tertinggi, yakni 767 persen. Disusul Qoo10 sebesar 586 persen. Shopee bahkan mendekati angka jumlah pengguna Tokopedia yang mencapai 13 juta. Shopee sendiri mencapai angka 10,8 juta pengguna. ${ }^{17}$

Tabel 1. Pertumbuhan Performa Kinerja E-Commerce dan Marketplace di Indonesia

\begin{tabular}{|c|c|c|c|c|c|c|c|}
\hline & & $\begin{array}{c}\text { Total Digital } \\
\text { Population } \\
(000)\end{array}$ & $\begin{array}{l}\text { Mobile } \\
(000)\end{array}$ & $\begin{array}{c}\text { Desktop } \\
(000)\end{array}$ & $\begin{array}{c}\text { Total } \\
\text { Minutes } \\
\text { (MM) }\end{array}$ & $\begin{array}{c}\text { Total Views } \\
\text { (MM) }\end{array}$ & $\begin{array}{c}\text { Avg } \\
\text { Minutes } \\
\text { per View }\end{array}$ \\
\hline 1 & Lazada.co.id & 23.235 & 15.864 & 8.107 & 526 & 552 & 1 \\
\hline 2 & Bibli.com & 15.556 & 13.837 & 2.651 & 635 & 422 & 1,5 \\
\hline 3 & Tokopedia.com & 14.401 & 13.006 & 2.217 & 1.548 & 326 & 4,7 \\
\hline 4 & Elevania.co.id & 12.872 & 9.535 & 5.130 & 438 & 285 & 1,5 \\
\hline 5 & MatahariMall.com & 12.520 & 11.516 & 1.879 & 410 & 516 & 0,8 \\
\hline 6 & Shopee.co.id & 11.301 & 10.872 & 763 & 2.169 & 136 & 16 \\
\hline 7 & Bukalapak.com & 10.407 & 8.971 & 2.203 & 459 & 193 & 2,4 \\
\hline 8 & Zalora.co.id & 9.052 & 8.636 & 813 & 396 & 493 & 0,8 \\
\hline 9 & Qoo10.co.id & 7.689 & 7.641 & 123 & 76 & 91 & 0,8 \\
\hline 10 & Blanja.com & 5.823 & 5.673 & 327 & 81 & 88 & 0,9 \\
\hline
\end{tabular}

Sumber: comScore MMX Multi-Platform, December 2017, Indonesia

15 https://www.idntimes.com/business/economy/yoshi/pertumbuhan-e-commerce-indonesia-1, (diakses 3 Juli 2018).

16 Ibid.

17 Ibid.

18 Ahmad Romsan mengatakan bahwa sebuah konflik tidak harus menjurus kepada pertikaian. Tetapi, konflik yang tidak mendapat penanganan dan penyelesaian secara baik akan menumpuk dan menjadi besar dan akan mempengaruhi perilaku atau sikap tindak manusia. Tentu saja pada akhirnya akan memerlukan sebuah penyelesaian. Lihat, Ahmad Romsan, Teknik Penyelesaian Sengketa di Luar Pengadilan: Negosiasi, Mediasi, dan Arbitrase, Cet-2, (Inderalaya: Bagian Hukum Internasional, Fakultas Hukum Universitas Sriwijaya, 2008), hlm. 4. 
Namun, tanpa disadari konflik (conflict) $)^{18}$ dan pertikaian (dispute) sering kali terjadi, tidak terkecuali dalam dunia perdagangan internasional. Dalam pergaulan masyarakat apalagi menyangkut transaksi bisnis internasional yang menggunakan e-commerce, muatan perbedaan antara tabiat dan kepentingan satu sama lain yang menghasilkan perselisihan dan pertikaian merupakan suatu yang lumrah. ${ }^{19}$ Namun tentunya, bukan hal yang mudah untuk mereduksi dan menghindari hal tersebut dalam konteks dunia bisnis.

Perselisihan dan pertikaian transaksi bisnis internasional yang menggunakan e-commerce tersebut disebabkan oleh adanya wanprestasi dari para pihak, baik itu pelaku usaha ataupun konsumen. Prof. Subekti dalam bukunya yang berjudul Hukum Perjanjian menyatakan bahwa wanprestasi (kelalaian atau kealpaan) seorang debitur dapat berupa empat macam, yaitu:20 1) Tidak melakukan apa yang disanggupi akan dilakukannya; 2) Melaksanakan apa yang dijanjikannya tetapi tidak sebagaimana mestinya; 3) Melakukan apa yang dijanjikan tetapi terlambat; 4) Melakukan sesuatu yang menurut perjanjian tidak boleh dilakukannya.

Terkait dengan wanprestasi tersebut, maka menurut penelitian yang dilakukan oleh sebuah lembaga internasional, telah banyak kasus yang merugikan konsumen sebagai akibat dari penggunaan media internet dalam transaksi perdagangan. Satu dari setiap sepuluh kasus pengiriman barang dapat dipastikan terlambat atau tidak sampai kepada konsumen. Contohnya: dua orang pembeli (buyers) dari Hongkong dan Inggris menunggu sampai lima bulan untuk mendapatkan refund (pembayaran kembali) dari barang yang dibeli, ada juga yang menerima barang tidak sesuai dengan pemesanan bahkan sampai barangnya tidak dikirim. Selain itu banyak juga penjual (suppliers atau sellers) yang tidak mampu memberikan kuitansi atau bukti transaksi dan sebagainya. ${ }^{21}$

Tidak hanya terkait dengan wanprestasi, sengketa dalam transaksi bisnis pun juga dapat terjadi karena adanya perbuatan melanggar hukum (onrechtmatigedaad) ${ }^{22}$. Salah satu unsur terpenting dari perbuatan melawan hukum tersebut adalah tuntutan ganti kerugian. ${ }^{23} \mathrm{Hal}$ inilah yang menjadi awal dari sengketa para pihak, yang apabila tidak muncul kesadaran secara damai akan menjadi sengketa yang berkepanjangan. ${ }^{24}$

Begitu juga halnya dengan perselisihan atau sengketa dalam transaksi bisnis internasional yang menggunakan e-commerce. Pada prinsipnya sengketa tersebut akan melibatkan beberapa negara yang berbeda sehingga dalam penyelesaian perselisihan atau sengketa tersebut akan menimbulkan beberapa masalah

19 Katsh, E., Rifkin, J. and Gaitenby, A., 1999. E-commerce, E-disputes, and E-dispute resolution: in the shadow of eBay law. Ohio St. J. on Disp. Resol., 15.

20 Subekti, Hukum Perjanjian, Cet-16, (Jakarta: PT. Intermasa, 1996), hlm. 45.

21 Didik M. Arief Mansur dan Elisatiris Gultom, Op. cit., hlm. 167.

22 Menurut Pasal 1365 KUHPerdata, perbuatan melanggar hukum adalah tiap perbuatan melanggar hukum yang membawa kerugian kepada orang lain, mewajibkan orang yang karena salahnya menerbitkan kerugian itu, mengganti kerugian tersebut. Lihat Kitab Undang-Undang Hukum Perdata (Burgerlijk Wetboek) diterjemahkan oleh R. Subekti dan R. Tjitrosudibio, Kitab Undang-Undang Hukum Perdata, Jakarta: Pradnya Paramita, 1983), hlm. 310.

23 Katsh, E., 2001. Online dispute resolution: Some lessons from the e-commerce revolution. N. Ky. L. Rev., 28.

24 Khotibul Umam, Penyelesaian Sengketa di Luar Pengadilan, Cet-1, (Yogyakarta: Pustaka Yustisia, 2010), hlm. 6. 
terutama forum yang berwenang dalam penyelesaian perselisihan sengketa. ${ }^{25}$

Dari uraian di atas, dapat diperhatikan bahwa perkembangan teknologi informasi dalam dunia ekonomi, disadari atau tidak disadari telah memberikan dampak terhadap perkembangan hukum. Bahkan, perkembangan teknologi informasi yang telah melahirkan model transaksi baru dalam dunia perdagangan internasional pun tidak luput dari timbulnya suatu sengketa dalam transaksi bisnis tersebut. Dalam tulisan ini akan banyak membahas aspek legislasi dan teori hukum terkait dengan forum manakah yang berwenang menangani penyelesaian sengketa transaksi bisnis internasional menggunakan e-commerce?

\section{B. Metode Penelitian}

Jenis pendekatan yang digunakan adalah penelitian hukum normatif yang bersifat kualitatif. Maksudnya adalah penelitian yang menggambarkan, menjelaskan, menganalisis, serta mengembangkan konstruksi hukum kedaulatan negara dalam perspektif imigrasi. ${ }^{26}$

Pengumpulan bahan-bahan hukum dilakukan dengan mengidentifikasi dan menginventarisasi peraturan perundangundangan, meneliti bahan pustaka (tulisan dan hasil karya ilmiah), dan sumber-sumber bahan hukum lainnya yang ada relevansinya dengan isu hukum dalam penelitian ini.

Teknik analisa isu hukum (legal issue) dalam penelitian ini menggunakan logika berpikir campuran. Maksudnya penalaran (hukum) yang merupakan gabungan dari pola berpikir induktif (inductive) dan deduktif (deductive) dalam persoalan hukum faktual yang konkrit. Proses yang terjadi dalam logika berpikir campuran adalah abstraksi (hukum), nilai-nilai hukum, asas-asas hukum, konsep-konsep hukum, dan norma-norma hukum yang dirumuskan secara umum dalam aturan-aturan hukum positif, kemudian dikonkritisasi (dijabarkan) dan diterapkan guna penyelesaian persoalan hukum konkrit yang dihadapi, begitu juga seterusnya secara bolak-balik dalam proses campuran. ${ }^{27}$

\section{Pembahasan}

\section{Forum yang Berwenang dalam Penyelesaian Sengketa dalam Transaksi Bisnis Internasional yang Menggunakan E-Commerce}

Forum yang berwenang menangani dalam penyelesaian sengekta transaksi bisnis internasional yang menggunakan e-commerce, diatur dalam Pasal 18 ayat (4) dan (5) UndangUndang No. 11 Tahun 2008 tentang Informasi dan Transaksi Elektronik (UU ITE).

Pasal 18 ayat (4) UU ITE menyatakan bahwa "para pihak memiliki kewenangan untuk menetapkan forum pengadilan, arbitrase, atau lembaga penyelesaian sengekta alternatif lainnya yang berwenang menangani sengketa yang mungkin timbul dari Transaksi Elektronik Internasional yang dibuatnya". Selanjutnya, dalam Pasal 18 ayat (5) dinyatakan bahwa "jika para pihak tidak melakukan pilihan forum sebagaimana dimaksud pada ayat

\footnotetext{
Fahroy, C.A. and Syahrin, M.A., 2016. Antara Batas Imajiner dan Kedaulatan Negara. Imigrasi di Batas Imajiner, Jakarta: Kantor Imigrasi Kelas I Khusus Soekarno Hatta.

26 Peter Mahmud Marzuki, Penelitian Hukum, (Jakarta: Kencana Prenada Media Group, 2005), hlm. 35.

27 Yudha Bhakti Ardhiswastra, Penafsiran dan Konstruksi Hukum, (Bandung: Alumni, 2008), hlm. 9; Saut P. Panjaitan, Dasar-Dasar Ilmu Hukum: Asas, Pengertian, dan Sistematika, (Palembang, Penerbit Universitas Sriwijaya, 1998), hlm. 158-159.
} 
(4), penetapan kewenangan pengadilan, arbitrase, atau lembaga penyelesaian sengketa alternatif lainnya yang berwenang menangani sengketa yang mungkin timbul dari transaksi tersebut, didasarkan pada asas Hukum Perdata Internasional".

\section{a. Kebebasan Para Pihak dalam Menentukan Pilihan Forum}

Kebebasan untuk memilih forum yang berwenang ini disebut juga sebagai "choice of forum". Namun, ada beberapa ahli yang menyebutnya sebagai "choice of jurisdiction". Secara terminologi, choice of forum, lebih menekankan kepada pemilihan forum (pengadilan, arbitrase, alternatif penyelesaian sengketa) yang berwenang dalam menyelesaian sengketa (d.h.i sengketa transaksi bisnis internasional yang menggunakan e-commerce). Sedangkan dalam choice of jurisdiction penetrasi maknanya lebih menekankan kepada pemilihan yurisdiksi kewenangan mengadili dari forum yang bersangkutan.

Hal serupa juga disampaikan oleh Gerarld Cooke dalam bukunya yang berjudul "Disputes Resolution in International Trading" yang menyatakan bahwa di antara kedua istilah tersebut (choice of forum dan choice of jurisdiction) mengandung pengertian yang agak berbeda. Menurutnya, istilah choice of forum berarti pilihan cara untuk mengadili sengketa, dalam hal ini pengadilan atau badan arbtirase. ${ }^{28}$ Sedangkan istilah choice of jurisdiction berarti pilihan tempat pengadilan memiliki kewenangan untuk menangani sengketa. ${ }^{29}$

Secara eksplisit, dalam ketentuan Pasal 18 ayat (4) UU ITE disebutkan bahwa para pihak telah diberikan kebebasan untuk menentukan sendiri forum mana yang berwenang dalam menangani sengketa yang timbul dari kontrak elektronik internasional yang dibuat oleh mereka tersebut. Inilah yang disebut dengan prinsip kebebasan berkontrak, yang dalam bahasa Inggris disebut dengan istilah "Party Autonomy" atau "Freedom of Contract". 30

Sesuai dengan asas kebebasan berkontrak ${ }^{31}$, maka para pihak dalam suatu perjanjian atau kontrak bebas menentukan isi dan bentuk suatu perjanjian, termasuk untuk menentukan forum. Kemudian apa yang telah disepakati oleh kedua belah pihak tadi berlaku sebagai undangundang bagi kedua belah pihak dalam suatu kontrak. ${ }^{32}$ Perlu diketahui bahwa kebebasan para pihak dalam suatu kontrak internasional

28 Syahrin, M.A., 2018. Menakar Kedaulatan Negara dalam Perspektif Keimigrasian. Jurnal Penelitian Hukum De Jure, 18(1), pp.43-57.

29 Gerald Cooke dalam Huala Adolf, Hukum Perdagangan Internasional, (Jakarta: PT. RajaGrafindo Persada, 2005), hlm. 208.

30 Munir Fuady, Buku Ke-2, Hukum Kontrak: Dari Sudut Pandang Hukum Bisnis, (Bandung: PT. Citra Aditya Bakti, 2003), hlm. 139.

31 Di dalam hukum kontrak, kebebasan berkontrak mencakup (i) kebebasan untuk membuat atau tidak membuat perjanjian; (ii) kebebasan untuk memilih dengan siapa ia ingin membuat perjanjian; (iii) kebebasan untuk menentukan atau memilih kuasa perjanjian yang akan dibuatnya; (iv) kebebasan untuk menentukan objek perjanjian; (v) kebebasan untuk menentukan isi perjanjian; (vi) kebebasan untuk menerima atau menyimpangi ketentuan-ketentuan undang-undang yang bersifat optional (aanvullendrecht). Lihat, Sutan Remy Sjahdenini, Kebebasan Berkontrak dan Perlindungan Hukum yang Seimbang bagi Para Pihak dalam Perjanjian Kredit Bank di Indonesia, (Jakarta: Institut Bankir Indonesia, 1993), hlm. 47.

31 Dalam sistem hukum Indonesia, prinsip ini dikenal dengan "pacta sun servanda". Secara yuridis hal ini diintrodusir dalam Pasal 1338 ayat (1) KUHPerdata. Berdasarkan prinsip ini, semua ketentuan dalam perjanjian atau kontrak yang dibuat oleh para pihak, akan menimbulkan kekuatan mengikat sebagaimana layaknya undang- 
untuk menundukkan kontrak mereka pada suatu forum tertentu, praktis merupakan prinsip yang diakui secara universal.

Terkait dengan kebebasan berkontrak, maka forum yang berwenang ini sedikit banyak akan bergantung ada kesepakatan para pihak. Forum yang berwenang tersebut dapat berupa forum nasional, arbitrase (nasional atau internasional), ataupun alternatif penyelesaian sengketa dari suatu negara tertentu. ${ }^{19}$

Dalam praktek, biasanya penentuan forum tersebut akan banyak dipengaruhi oleh nasionalitas salah satu pihak. Cara pemilihan inilah yang lazim ditetapkan dewasa ini. Apabila salah satu pihak atau kedua belah pihak tidak sepakat mengenai salah satu hukum nasional tersebut, maka kemudian mereka akan berupaya mencari forum penyelesaian sengketa yang relatif lebih netral. ${ }^{20}$

b. Penentuan Forum yang Berwenang Berdasarkan Konvensi Brussels atau EC Council Regulation on Jurisdiction and the Recognition and Enforcement of Judgments in Civil and Commercial Matters (2001)

Terkait dengan permasalahan awal yang dibahas, maka dalam Konvensi Brussels atau EC Council Regulation on Jurisdiction and the Recognition and Enforcement of Judgments in Civil and Commercial Matters (2001), dikenal ada beberapa asas-asas HPI yang dapat digunakan untuk menentukan forum ${ }^{21}$ (bilamana dalam kontrak yang dibuat oleh para pihak tersebut tidak disebutkan mengenai pilihan forum) dalam menyelesaikan suatu sengketa (d.h.i sengketa transaksi bisnis internasional yang menggunakan e-commerce), yaitu: ${ }^{22}$

1) Asas Forum Rei

Asas forum rei (tempat forum berada) yang sebenarnya sama dengan asas "actor sequitur forum rei" dan menjadi asas utama bagi pengadilan untuk mengklaim yurisdiksi atas seseorang tergugat yang berdomisili atau berkediaman sehari-hari di wilayah negara forum.

2) Asas Forum Solutionis Contractus

Yaitu asas yang menjadi dasar penetapan yurisdiksi bagi forum dari tempat dimana suatu perikatan dianggap telah dilaksanakan atau seharusnya dilaksanakan.

3) Asas Pengadilan Tempat Pihak yang Berkedudukan Lebih Lemah

Yaitu asas yang memberikan kewenangan yurisdiksional pada pengadilan dari tempat dimana pihak dalam transaksi hukum yang dianggap berkedudukan lebih lemah, khususnya dalam rangka memberikan perlindungan pada pihak konsumen dalam transaksi-transaksi konsumen atau pihak buruh dalam transaksi dalam hubungan kerja.

4) Pemunculan Secara Sukarela (Voluntary Appearance)

Yang menetapkan bahwa dalam hal seorang tergugat secara sukarela tampil di sebuah

undang. Terkait dengan e-commerce, maka segala sesuatu ketentuan yang terkait dengan transaksi elektronik yang kemudian dituangkan ke dalam kontrak elektronik adalah mengikat bagi para pihak. Baca Indonesia, Undang-Undang tentang Informasi dan Transaksi Elektronik, UU No. 11 Tahun 2008, LN Tahun 2008 Nomor 58, (selanjutnya disebut UU ITE), Pasal 18 ayat (1).

19 Syahrin, M.A., 2017. The Implementation of Non-Refoulement Principle to the Asylum Seekers and Refugees in Indonesia. Sriwijaya Law Review, 1(2), pp.168-178.

20 Syahrin, M.A., 2017. Konsep Teoretis Penyelesaian Sengketa Hukum E-Commerce. Mahara Publishing.

21 Syahrin, M.A., 2017. E-Commerce: Pilihan Hukum dan Pilihan Forum. Mahara Publishing.

22 Ibid., hlm. 198-201. 
forum pengadilan asing untuk membela dirinya dalam pokok perkara (dan bukan sekedar untuk menyatakan bahwa forum asing itu tidak kompeten), forum asing itu akan dianggap memiliki yurisdiksi atas si tergugat. Asas ini hanya dapat digunakan dalam hal forum pengadilan tidak memiliki yurisdiksi eksklusif atas perkara.

5) Asas Forum Rei Sitae

Yaitu asas yang dapat menjadi dasar penetapan kewenangan yurisdiksional forum atas perkara-perkara yang menyangkut hak kebendaan atas benda-benda tetap (immovables) yang terletak di wilayah forum. Asas ini sama dengan konsep in rem jurisdiction.

6) Yurisdiksi atas Kantor Cabang, Agensi, dan Badan-Badan Lain

Yaitu asas yang dianggap ada pada pengadilan asing tempat di dimana perkara timbul dari beroperasinya cabang, agen, atau badan sejenis terletak.

7) Asas Forum Delicti

Yaitu asas yang digunakan untuk penentuan adanya kewenangan yurisdiksional dalam perkara-perkara perbuatan melawan hukum (tort, onrechtmatigedaad) yang dimiliki oleh forum tempat perbuatan dilakukan atau tempat dimana kerugian (injury) akibat perbuatan melawan hukum itu timbul.

8) Asas Forum Connexitatis

Yaitu asas penetapan yurisdiksi yang memberikan kewenangan mengadili pada forum yang telah memiliki yurisdiksi untuk memeriksa pokok perkara dan juga memeriksa gugat balik (counterclaims) atau gugatan pihak ketiga (third party processdings). Asas ini hanya dapat digunakan apabila tidak ada forum lain yang memiliki yurisdiksi eksklusif atau yurisdiksi karena pilihan para pihak.

9) Asas Forum Arresti

Yaitu asas yang dalam perkara-perkara yang menyangkut muatan barang atau kapal yang ditahan untuk jaminan utang memberikan kewenangan yurisdiksional pada pengadilan di tempat kapal atau muatan kapal itu ditahan.

Sementara itu dalam Principle 2.1 bagian (2) dari PTCP (tentang Jurisdiction over Parties) dikemukakan beberapa prinsip yang dapat digunakan untuk menetapkan yurisdiksi pengadilan atas salah satu pihak dalam sengketa (d.h.i sengketa transaksi binsis internasional). Prinsip tersebut menyatakan bahwa "yurisdiksi pengadilan atas salah satu pihak dalam perkara dapat dilaksanakan, apabila terdapat kaitan yang substansial (substansial connection) antara negara forum dan para pihak yang bersengketa atau transaksi atau peristiwa yang menjadi pokok sengketa". ${ }^{23}$

Lebih jauh prinsip ini menetapkan ukuran adanya substansial connection, dengan pendekatan: ${ }^{24}$

a) Bila bagian yang signifikan dari transaksi atau peristiwa hukum yang menjadi sengketa terjadi di negara forum;

b) Bila seorang tergugat memiliki tempat kediaman sehari-hari negara forum;

c) Bila sebuah badan hukum telah menerima pengesahan akta pendiriannya atau memiliki tempat utama pelaksanaan bisnisnya (principal place of business) di negara forum; 
d) Bila benda (property) yang berkaitan dengan perkara terletak di negara forum.

Dalam asas/prinsip tersebut mengandung makna bahwa suatu forum (baik itu pengadilan, arbitrase, ataupun alternatif penyelesaian sengketa) dapat diterapkan (dalam hal tidak ada choice of forum) apabila ada keterkaitan yang erat dan substansial antara negara forum yang bersangkutan dengan para pihak yang bersengketa.

Asas ini sangat tepat digunakan untuk menentukan forum mana yang berwenang dalam penyelesaian sengketa transaksi internasional yang menggunakan e-commerce, karena dapat mengakomodir berbagai macam karakteristik dari transkasi bisnis e-commerce itu sendiri. ${ }^{25}$ Selain itu juga, asas ini juga dapat meminimalisir dan menutupi kelemahankelemahan yang ada dalam asas-asas HPI yang lainnya. Seperti, asas forum rei (actor sequitur forum rei) yang menjelaskan bahwa forum yang berwenang adalah forum dimana tergugat mengajukan gugatannya atas dasar kediaman dan domisili dari tergugat dan asas forum solutionis contractus yang menghendaki dasar dari penetapan suatu forum adalah dimana suatu perikatan (kontak) tersebut dilaksanakan. ${ }^{26}$

Bila dikaitkan dengan ukuran penetapan substansial connection tersebut, maka point yang cukup relevan dengan penyelesaian sengketa transaksi bisnis internasional yang menggunakan e-commerce adalah point pertama, yaitu "bila bagian yang signifikan dari transaksi atau peristiwa hukum yang menjadi sengketa terjadi negara forum". ${ }^{27}$

Sebagaimana kita ketahui bahwa transaksi bisnis internasional yang menggunakan e-commerce, secara karakteristik dan prosedural tentunya sangat berbeda dengan transaksi bisnis konvensional lainnya. Dalam transaksi bisnis konvensional, para pihak dapat ditentukan dengan mudah, baik itu mengenai kedudukannya ataupun identitasnya secara jelas. Tidak hanya itu, terkadang tempat dimana pelaksanaan kontrak para pihak pun sukar untuk ditentukan. Oleh karenanya, point lain seperti yang diuraikan dari yang kedua hingga keempat, tidak cukup relevan apabila diterapkan dalam penyelesaian sengketa transaksi bisnis internasional yang menggunakan e-commerce.

Secara sederhana, asas substansial connection forum ini sama persis dengan asas / teori dalam penentuan hukum yang berlaku, yaitu the most characteristic connection theory. Dimana yang dijadikan tolak ukur sebagai penentuan hubungan yang paling karakteristik adalah didasari atas pihak mana yang akan melakukan prestasi yang paling khas dalam suatu kontrak. Misalnya dalam ruang lingkup kontrak online, contoh-contoh dari prestasi yang karakteristik adalah mencakup pengiriman barang dan penyediaan jasa layanan atau pelayanan digital. Hal inilah yang merupakan inti kontrak, bukan pembayarannya. Melihat fakta-fakta karakteristik di atas, maka forum yang berlaku dalam kontrak online, khususnya terkait dengan transaksi bisnis internasional

25 Martin, M.S., 2002. Keep it online: The Hague Convention and the need for online alternative dispute resolution in international business-to-consumer e-commerce. BU Int'l LJ, 20.

26 Syahrin, M.A., 2017. Actio Pauliana: Konsep Hukum dan Problematikanya. Lex Librum: Jurnal Ilmu Hukum, 4(1).

27 Syahrin, M.A., 2017. Refleksi Teoretik E-Contract: Hukum yang Berlaku dalam Sengketa Transaksi Bisnis Internasional yang Menggunakan E-Commerce. Lex Librum: Jurnal Ilmu Hukum, 3(2). 
yang menggunakan e-commerce adalah forum dimana tempat si penjual berada.

Berdasarkan uraian di atas, maka penulis berpendapat bahwa kehadiran asas substansial connection forum ini dapat menjadi solusi yang tepat dalam penyelesaian sengketa transaksi bisnis internasional yang menggunakan e-commerce.

\section{Model Penyelesaian Sengketa Transaksi Bisnis Internasional yang Menggunakan E-Commerce}

Terkait dengan model penyelesaian sengketa yang digunakan (baik itu melalui mekanisme pemilihan dalam kontrak ataupun asas-asas HPI), maka secara jelas Pasal 18 ayat (4) dan (5) UU ITE telah menyebutkan bahwa "...forum pengadilan, arbitrase, atau lembaga penyelesaian sengketa alternatif lainnya...". Berikut ini bagan model penyelesaian sengketa transaksi bisnis internasionalyang menggunakan e-commerce menurut Pasal 18 ayat (4) dan (5) UU ITE tersebut:

Bagan 2. Model Penyelesaian Sengketa Transaksi Bisnis Internasional yang Menggunakan E-Commerce

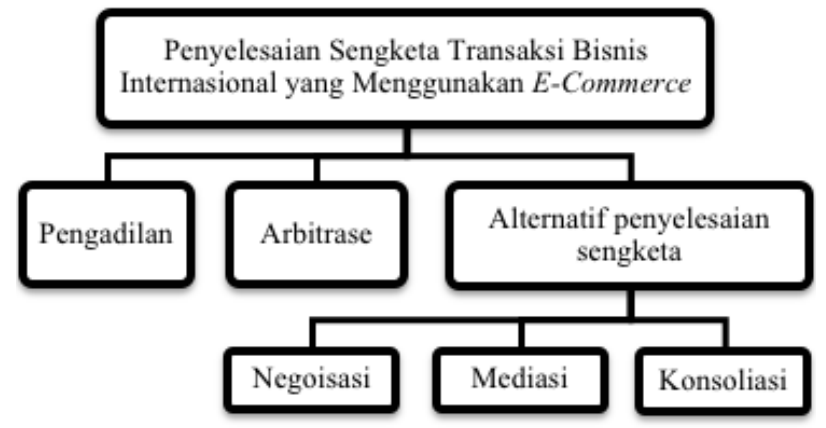

Untuk lebih memahami bagan tesebut di atas, maka penulis akan menjelaskan secara detail dan sistematis dalam uraian singkat di bawah ini:

\section{a. Pengadilan (Litigasi)}

Adanya kebebasan berkontrak dari para pihak untuk menentukan forum pengadilan yang berwenang dalam penyelesaian sengketa tersebut (d.h.i sengketa transaksi bisnis internasional), sejatinya telah diatur dan diakomodir dalam Principle 2.1 bagian (1) dari $P T C P^{28}$ (tentang Jurisdiction over Parties). Prinsip tersebut mengemukakan "bahwa yurisdiksi pengadilan terhadap salah satu pihak dalam perkara dapat dilaksanakan atas kesepakatan para pihak yang berperkara untuk mengajukan sengketa mereka ke depan pengadilan yang bersangkutan". Ketentuan ini setidaknya menjadi acuan yuridis terkait dengan penentuan forum pengadilan atas dasar kebebasan berkontrak para pihak. ${ }^{29}$

Dalam pelaksanaannya, proses litigasi menghasilkan kesepakatan yang bersifat adversarial yang belum mampu merangkul kepentingan bersama dan cenderung menimbulkan masalah baru, lambat dalam penyelesaian, membutuhkan biaya yang mahal, tidak responsif, serta menimbulkan permusuhan di antara para pihak yang bersengketa. ${ }^{30}$

Lebih lanjut, walaupun beberapa ahli berpendapat bahwa pengadilan merupakan model penyelesaian sengketa terburuk, namun

28 Principles of Transnational Civil Procedure (2004)-(PTCP) merupakan sekumpulan asas dan aturan-aturan hukum acara perdata transnational sebagai hasil kolaborasi antara UNIDROIT dan The American Law Institute, yang digunakan untuk mengharmonisasikan asas dan aturan hukum acara perdata dalam penyelesaian perkaraperkara perdagangan internasional. Periksa, Bayu Seto, Buku ke-1 (Edisi Keempat), Dasar-Dasar Hukum Perdata Internasional, (Bandung: PT. Citra Aditya Bakti, 2006), hlm. 201.

29 Ibid., hlm. 202.

30 Rachmadi Usman, Pilihan Penyelesaian Sengketa di Luar Pengadilan, (Bandung: PT. Citra Aditya Bakti, 2003 ), hlm. 3. 
di lain sisi pengadilan tetap memiliki keunggulan tersendiri. Di antara keunggulan dari pemilihan pengadilan ini adalah: ${ }^{31}$

1) Bahwa pengadilan tersebut lebih mengetahui hukum yang berlaku, jika dipilih pengadilan yang terletak di tempat atau di negara yang juga dipilih hukumnya;

2) Bahwa pengadilan tersebut lebih mengetahui kasus bersangkutan, jika yang dipilih adalah pengadilan tempat terjadinya kasus atau tempat dilaksanakannya kontrak tersebut;

3) Bahwa pengadilan tersebut dan para pihak lebih banyak akses ke alat bukti, termasuk alat bukti saksi jika yang dipilih adalah pengadilan tempat terjadinya kasus atau tempat dilaksanakannya kontrak tersebut.

Penyelesaian sengketa dagang (d.h.i sengketa transaksi bisnis internasional yang menggunakan e-commerce) melalui pengadilan (litigasi) biasanya hanya dimungkinkan ketika para pihak sepakat. Kesepakatan ini tertuang dalam klausul penyelesaian sengketa dalam kontrak bisnis para pihak. Dalam konteks internasional, isi klausula tersebut biasanya ditegaskan bahwa jika timbul sengketa dari hubungan bisnis mereka, maka mereka sepakat untuk menyerahkan sengketanya tersebut kepada suatu pengadilan (negeri) suatu negara tertentu. ${ }^{32}$

Dalam praktek penyelesaian sengketa transaksi bisnis internasional, dikenal adanya pengadilan-pengadilan permanen internasional. ${ }^{33}$ Pengadilan ini kadang kala yurisdiksinya terbatas hanya kepada negara saja, misalnya Mahkamah Internasional. Sementara itu, kegiatan-kegiatan atau hubungan perdagangan internasional dewasa ini peranan subjek-subjek hukum perdagangan internasional non-negara juga sangatlah penting, tidak hanya perorangan. ${ }^{34}$

Bentuk pengadilan lain adalah pengadilan ad hoc atau pengadilan khusus. Dibandingkan dengan pengadilan permanen, pengadilan ad hoc atau khusus ini lebih populer, terutama dalam kerangka suatu organisiasi perdagangan internasional. Badan pengadilan ini berfungsi cukup penting dalam menyelesaikan sengketasengketa yang timbul dari perjanjian-perjanijan perdagangan internasional. ${ }^{35}$ Contoh yang menonjol adalah peranan badan-badan pengadilan khusus dalam kerangka GATT (kemudian digantikan oleh WTO), yakni dengan adanya badan-badan panel yang menyelesaikan sengketa-sengketa ekonomi internasional antar negara-negara anggota GATT/WTO. ${ }^{36}$

Namun demikian, pilihan forum (choice of forum) ini dapat menyimpan masalah yang serius jika pengadilan yang dipilih bukan pengadilan di negara tempat dieksekusinya putusan pengadilan. ${ }^{37}$ Misalnya, jika yang dipilih bukan pengadilan di negara tempat dimana aset tergugat terletak. Sebab, banyak negara termasuk Indonesia tidak mempunyai kewajiban untuk mengeksekusi putusan pengadilan asing, sehingga putusan yang sudah dimenangkan oleh salah satu pihak tidak akan dapat dieksekusi.

\footnotetext{
Munir Fuady, Op. cit., hlm. 146-147.

Huala Adolf, Op. cit., hlm. 210.

Nadler, J., 2001. Electronically-mediated dispute resolution and e-commerce. Negotiation Journal, 17(4).

Ibid., hlm. 212.

Ibid., hlm. 212-213.

Ibid., hlm. 213.

Panagariya, A., 2000. E-commerce, WTO and developing countries. The World Economy, 23(8).
} 
Kecuali jika yang dipilih adalah badan arbitrase, dimana dengan beberapa batasan yang tidak terlalu ketat, umumnya negara-negara dapat mengeksekusi putusan arbitrase asing. ${ }^{38}$

Terkait dengan penyelesaian sengketa (d.h.i sengketa transaksi bisnis internasional yang menggunakan e-commerce) melalui pengadilan, banyak para ahli yang berpendapat bahwa penyelesaian model ini sangat tidak merepresentasikan tujuan yang hendak dicapai dalam dunia bisnis. ${ }^{39}$ Banyak sengketa yang diselesaikan oleh badan peradilan yang memakan biaya yang besar dan waktu yang lama. Hal ini menimbulkan sinisme dari berbagai pihak, termasuk Abraham Lincoln pada tahun 1850 . la menyatakan bahwa "discourege litigation, persuade your neighbours to compromise whenever you can, point out to them how the nominal winner is often a real losser-infus, expence, and waste of time" (hindari perkara di pengadilan sedapat mungkin bujuk lawanmu untuk berkompromi, tunjukkan kepada mereka pada dasarnya pihak yang menang berperkara adalah pihak yang kalah, karena untuk memperoleh kemenangan itu dia harus mengeluarkan biaya yang mahal dan membuang waktu yang lama). ${ }^{40}$

\section{b. Arbitrase}

Menurut Rv., arbitrase merupakan suatu bentuk peradilan yang diselenggarakan oleh dan berdasarkan kehendak serta itikad baik dari pihak-pihak yang berselisih agar perselisihan mereka tersebut diselesaikan oleh hakim (hakim) yang mereka tunjuk dan angkat sendiri, dengan pengertian bahwa putusan yang diambil oleh hakim (hakim) tersebut merupakan putusan yang bersifat final (putusan pada tingkat terakhir) dan yang mengikat kedua belah pihak untuk melaksanakannya. ${ }^{41}$

Sedangkan menurut Gary Goodpaster, "arbitration is the private adjutication of dispute Parties, anticipating possible dispute or experiencing an actual dispute, agree to submit their dispute to a decision maker they in some fashion select". ${ }^{42}$

Dengan mengacu pada konvensi-konvensi, seperti Convention of the Settlement of Investment Disputes Between States and National of Other State atau Convention on the Recognition and Enforcement of Foreign Arbitral Awards (Konvensi New York 1958) ${ }^{43}$, maupun berdasarkan ketentuan yang terdapat dalam UNCITRAL Arbitration Rules, maka kita

$38 \quad$ Ibid., hlm. 147.

39 Cara penyelesaian sengketa yang diinginkan dan dituntut dalam dunia bisnis adalah sistem penyelesaian sederhana, cepat, dan biaya ringan atau informal procedure and can be put in motion quickly. Dalam arti: penyelesaian sengketa tetap berada dalam jalur sistem yang formal dan resmi serta dibenarkan oleh hukum yang lazim disebut sebagai formal and official law enforcement system dan tidak dibenarkan dengan cara secondary enforcement system yaitu sistem yang membawa malapetaka dengan membenarkan segala cara demi mencapai tujuan. Secara yuridis formal, sistem penyelesaian sengketa sederhana, cepat, dan biaya ringan ini pada dasarnya telah diakomodir sebagai asas dalam peradilan Indonesia, yaitu Pasal 2 ayat (4) UU No. 48 Tahun 2009 tentang Kekuasaan Kehakiman. Sehingga dalam pelaksanaannya, asas ini telah menjadi suatu fundamentum dalam pelaksanaan fungsi peradilan. Baca Yahya Ahmad Zein, Op. cit., hlm. 92.

$40 \quad$ Ibid., hlm. 99.

41 Gunawan Widjaja dan Ahmad Yani, Hukum Arbitrase, (Jakarta: PT. RajaGrafindo Persada, 2000), hlm. 16.

42 Rachmadi Usman, Hukum Arbitrase Nasional, (Jakarta: Grasindo, 2002), hlm. 2.

43 Konvensi ini ditandatangani di New York pada tanggal 7 Juni 1959. Secara yuridis, konvensi ini telah disahkan (diratifikasi) oleh pemerintah Indonesia dengan Keputusan Presiden Nomor 34 Tahun 1981. Ini berarti New York Convention tersebut, sejak tanggal 5 Agustus 1981 telah berlaku dan dapat diterapkan di Indonesia. 
dapat mengemukakan beberapa jenis arbitrase, yaitu: ${ }^{44}$

1) Arbitrase Ad Hoc (arbitrase volunteer)

Merupakan arbitrase yang dibentuk khusus untuk menyelesaikan atau memutus perselisihan tertentu. Arbitrase ini bersifat insidental dan jangka waktunya tertentu sampai sengketa itu diputuskan.

2) Arbitrase Institusional

Merupakan lembaga atau badan arbitrase yang sifatnya permanen. Oleh karenannya, sering disebut juga "permanent body", sebagaimana dinyatakan dalam Pasal 1 ayat (2) Konvensi New York 1958. Arbitrase ini disediakan oleh organisasi tertentu dan sengaja didirikan untuk menampung perselisihan yang timbul dari perjanjian.

Berikut 14 macam arbitrase yang khusus didesain untuk perkara-perkara bisnis internasional (d.h.i sengketa transaksi bisnis internasional yang menggunakan e-commerce), yang berhasil diintrodusir oleh Munir Fuady, yaitu: ${ }^{45}$

a) International Chamber of Commerce (ICC $)^{46}$ didirikan pada tahun 1923

b) London Court of International Arbitration (LCIA) didirikan pada tahun 1982

c) Australian Centre for International Commercial Arbitration (ACICA) di Australia

d) Singapore International Arbitration Centre (SIAC) yang didirikan pada tahun 1991

e) Regional Centre for Arbitration di Kuala Lumpur yang didirikan pada tahun 1978 f) Regional Centre for Arbitration di Kairo, atau yang disebut dengan Asian-African Legal Consultative Commitee

g) British Columbia International Commercial Arbitration Centre yang didirikan pada tahun 1986

h) Hongkong International Arbitration Centre di Hongkong yang didirikan pada tahun 1985

i) China International Economic and Trade Arbitration Commssion (CIETAC)

j) Vietnam International Arbitration Centre (VIAC)

k) The International Centre for the Settlement of Investment Disputes (ICISD)

I) Interamerican Commission on Commercial Arbitration

m) The International Commercial Arbitration Court (ICAC) di Rusia

n) The Arbitration (Tretejskyi) Court for Settlement of Economic Disputes di Rusia.

\section{c. Negosiasi}

Secara historis, negosiasi merupakan cara penyelesaian sengketa yang paling dasar dan yang paling tua digunakan. Penyelesaian melalui negosiasi merupakan cara yang paling penting. Banyak sengketa yang diselesaikan oleh negosiasi setiap hari, tanpa adanya publisitas yang menarik perhatian publik. ${ }^{47}$

Tim Hindle dalam bukunya yang berjudul "Negotiating Skills", mengatakan bahwa: "negosiasi yang baik adalah usaha 2 (dua) orang (para pihak) untuk mencapai penyelesaian yang dapat diterima bersama, tidak menghasilkan

\footnotetext{
Gunawan Widjaja dan Ahmad Yani, Op. cit., hlm. 52-53.

45 Munir Fuady, Arbitrase Nasional: Alternatif Penyelesaian Sengekta Bisnis, (Bandung: PT. Citra Aditya Bakti, 2003), hlm. 18-19.

46 Lembaga arbitrase ini didirikan sesudah Perang Dunia I pada tahun 1919 yang berkedudukan di Paris. Badan arbitrase internasional ini bertugas menyelesaikan sengketa di bidang perdagangan dimana para pihak yang bersengketa berbeda kewarganegaraan.

47 Huala Adolf I, hlm. 201.
} 
pemenang dan pecundang". Inti dari negosiasi adalah tawar-menawar antara para pihak. Negosiasi terjadi apabila orang lain memiliki apa yang kita inginkan dan kita bersedia menukarnya dengan apa yang diinginkan mereka. ${ }^{48}$

Sama halnya dengan metode penyelesaian sengketa alternatif lainnya, negosiasi harus didasarkan atas kesepakatan atau konsensus para pihak. Hal ini dipertegas oleh Kohona yang menyatakan bahwa negosiasi adalah "an efficacious means of settling disputes relating to an agreement because they enable parties to arrive at conclusions having regrard to the wishes of all the disputants". ${ }^{49}$

Berikut ini bagan tahapan/proses negosiasi dalam penyelesaian sengketa transaksi bisnis internasional yang menggunakan e-commerce:

Bagan 3. Proses Negosiasi

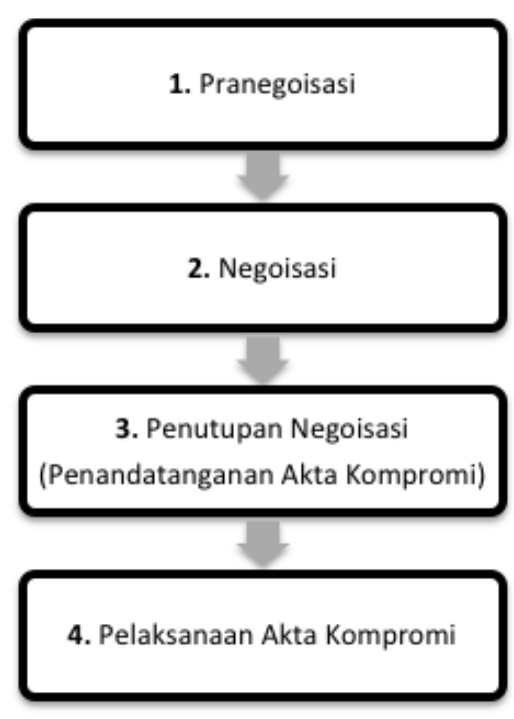

Untuk lebih memahami bagan tersebut di atas, maka penulis akan menjelaskan secara detail dan sistematis dalam uraian singkat di bawah ini: ${ }^{50}$

\section{1) Tahap Pra Negosiasi}

Pada tahap ini masing-masing pihak melakukan persiapan untuk menghadapi proses negosiasi. Kegiatan yang dilakukan bersifat internal. Masing-masing pihak tanpa melibatkan pihak lainnya. Kegiatan yang dilakukan pada tahap ini adalah:

a) menentukan tujuan dan menetapkan posisi

b) melengkapi data (baik data pribadi maupun data pihak lawan)

c) mempersiapkan tim negoisator

d) menentukan strategi awal.

\section{2) Tahap Negosiasi}

Tahap inilah negosiasi yang sesungguhnya. Para pihak bertemu dan berhadapan muka di meja perundingan. Tempat yang digunakan berdasarkan kesepakatan para pihak, biasanya di hotel, kantor, ataupun rumah. Tahap ini terdiri dari 4 (empat) kegiatan, yaitu:

a) presentasi dari para pihak

b) proses perundingan atau tawar-menawar solusi

c) merumuskan draft kesepakatan

d) tahap penandatanganan hasil negosiasi.

Tahap ini merupakan penutup dari proses negosiasi. Para pihak yang diwakili oleh orang berwenang membubuhkan tanda tangan pada akta kesepakatan (akta perdamaian atau akta kompromi) sebagai tanda setuju dan berkomitmen untuk melaksanakan isinya secara bertanggung jawab. Hal ini sesuai dengan ketentuan Pasal 6 ayat (2) Undang-Undang No. 30 Tahun 1999 tentang Arbitrase dan Alternatif Penyelesaian Sengketa yang menyatakan bahwa penyelesaian sengketa atau beda pendapat

\footnotetext{
48 Tim Hindle dalam Candra Irawan, Op. cit., hlm. 30.

49 Huala Adolf I, hlm. 201.

50 Candra Irawan, Op. cit., hlm. 32-41.
} 
melalui alternatif penyelesaian sengketa (APS) dalam pertemuan langsung para pihak (negosiasi) diselesaikan dalam waktu paling lama 14 hari dan hasilnya dituangkan dalam kesepakatan tertulis.

\section{3) Tahap Pelaksanaan Akta Perdamaian}

Kemudian Pasal 6 ayat (2), memberi ketentuan bahwa kesepakatan penyelesaian sengketa atau beda pendapat secara tertulis adalah final dan mengikat para pihak untuk melaksanakannya dengan itikad baik serta wajib didaftarkan di Pengadilan Negeri dalam waktu paling lama 30 hari sejak penandatanganan dan Pasal 6 ayat (8) menyatakan bahwa kesepakatan penyelesaian sengketa wajib selesai dilaksanakan dalam waktu paling lama 30 hari sejak pendaftaran. Dalam hal pelaksanaan akta kesepakatan, sepanjang para pihak melaksanakan sendiri secara sukarela maka tidak perlu ada pendaftaran akta kesepakatan di Pengadilan Negeri. Namun jika dikhawatirkan ada pihak yang akan melanggar isi kesepakatan maka pendaftaran tersebut perlu dilakukan.

Terkait dengan pelaksanaan negosiasi, prosedur-prosedur yang terdapat di dalamnya perlu dibedakan sebagai berikut: ${ }^{51}$

a) Negosiasi digunakan ketika suatu sengketa (d.h.i sengketa transaksi bisnis internasional yang menggunakan e-commerce) belum lahir (disebut sebagai konsultasi);

b) Negosiasi digunakan ketika sengketa (d.h.i sengketa transaksi bisnis internasional yang menggunakan e-commerce) telah lahir.
Prosedur ini merupakan proses penyelesaian sengketa oleh para pihak (dalam arti negosiasi).

\section{d. Mediasi}

Menurut Black's Law Dictionary, dikatakan bahwa "mediation is private, informal dispute resolution process in which a neutral third person, the mediator, help disputing parties to reach an agreement". ${ }^{52}$

Sedangkan pengertian mediasi dalam arti luas diberikan oleh The National Alternative Dispute Council yang menyatakan bahwa "mediation is a process in which the parties to a dispute, with the assistance of a dispute resolution practioner (a mediator), identify the dispute issues, develop options, consider alternatives and endeavour to reach an agreement. The mediator has no advisory or determinative role in regrad to the content of dispute or the outcome of its resolution, but may advise on or determine the process of mediation whereby resolution is attempted". ${ }^{53}$

Seperti halnya dalam negosiasi, tidak ada prosedur-prosedur khusus yang harus ditempuh dalam proses mediasi. Para pihak bebas untuk menentukan prosedurnya. Hal yang penting adalah kesepakatan para pihak mulai dari proses (pemilihan) cara mediasi, menerima, atau tidaknya usulan-usulan yang diberikan mediator sampai kepada pengakhiran tugas mediator. ${ }^{54}$

Gerald Cooke menggambarkan kelebihan mediasi sebagai berikut: "where mediation 
is succesfully used, it generally provides a quick, cheap, and effective result. It is clearly appropriate, therefore, to consider providing for mediation or other alternative dispute resolution techniques in the contractual dispute resolution clause." (huruf tebal oleh penulis). ${ }^{55}$

Bagan 4. Proses Mediasi

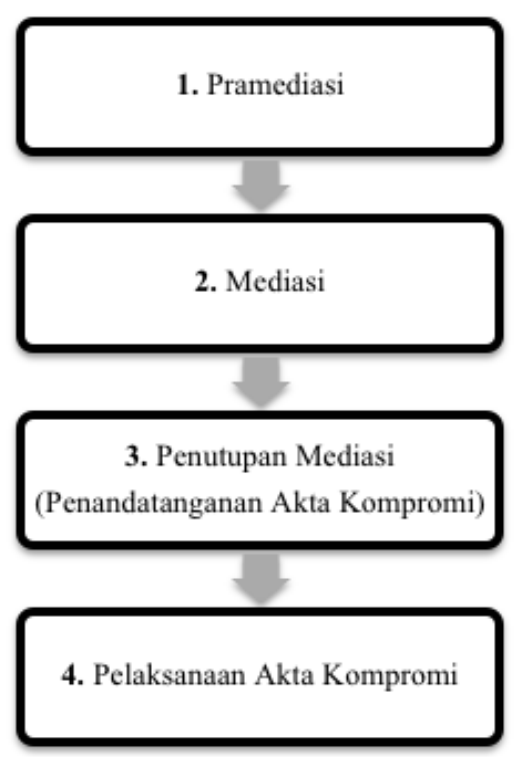

Untuk lebih memahami bagan tersebut di atas, maka penulis akan menjelaskan secara detail dan sistematis dalam uraian singkat di bawah ini: ${ }^{56}$

\section{1) Tahap Pramediasi}

Tahap ini berisi kegiatan-kegiatan:

a) Para pihak bersepakat menunjuk mediator secara tertulis dan mediator menerima penunjukan tersebut secara tertulis;

b) Mediator mulai mengindentifikasi para pihak, menganalisa sengketa dan berusaha bertemu dengan para pihak dan mempertemukan para pihak, memperkenalkan diri, menegaskan posisi sebagai pihak ketiga independen, dan membantu para pihak mengakhiri sengketa secara damai, dan lain sebagainya.

\section{2) Tahap Pelaksanaan Mediasi}

Kegiatan-kegiatan yang dilakukan pada tahap ini adalah:

a) Mediator membuka forum mediasi;

b) Pernyataan (statement) dari masing-masing pihak. Pernyataan para pihak antara lain berisi ilustrasi kasus, penegasan posisi, keinginan (tujuan), komitmen, dan tawarmenawar;

c) Mediator mengisolasi masalah agar tetap fokus dan tidak melebar;

d) Terjadi proses negosiasi antara para pihak. Para pihak saling menawarkan kemungkinan untuk mencakapi kesepakatan. Mediator berperan mengarahkan, mengingatkan, dan berusaha menggiring para pihakmenemukan solusi yang saling menguntungkan;

e) Mediator memunculkan berbagai kemungkinan solusi yang dapat dipilih untuk mempertemukan keinginan masing-masing pihak.

\section{3) Penutupan mediasi}

Kegiatan-kegiatan yang dilakukan adalah:

a) Penandatanganan akta kompromi;

b) Mediator menegaskan komitmen pelaksanaan akta kompromi secara sukarela dan bertanggung jawab.

\section{4) Pelaksanaan akta perdamaian}

Menurut Pasal 6 ayat (7) UU No. 30 Tahun 1999 tentang Arbitrase dan Alternatif Penyelesaian Sengketa dinyatakan bahwa 
sebelum dilaksanakannya akta kompromi, maka akta perdamaian tersebut harus didaftarkan di Pengadilan Negeri paling lambat 30 (tiga puluh) hari sejak ditandatangani dan harus sudah dilaksanakan dalam waktu paling lama 30 (tiga puluh) hari sejak didaftarkan.

\section{e. Konsiliasi}

Secara sederhana yang dimaksud dengan konsiliasi adalah usaha yang dilakukan oleh pihak ketiga yang bersifat netral untuk berkomuniksi dengan kelompok-kelompok yang bersengketa secara terpisah, dengan tujuan mengurangi ketegangan dan mengusahakan ke arah tercapainya persetujuan untuk berlangsungnya suatu proses penyelesaian sengketa (d.h.i sengketa transaksi bisnis internasional yang menggunakan e-commerce). ${ }^{58}$

Sedangkan dalam Black's Law Dictionary, dikatakan bahwa "consiliation is the adjusment and settlement of a dispute in a friendly, unantagontic manner used in courts before trial with a view towards avoiding trial and in labor disputes before arbitration". ${ }^{59}$

Secara yuridis, proses penyelesaian sengketa konsiliasi (d.h.i sengketa transaksi bisnis internasional yang menggunakan e-commerce) mengacu pada pola penyelesaian secara konsensus, yaitu pihak netral dapat berperan secara aktif ataupun pasif. ${ }^{60} \mathrm{Hal}$ ini serupa dengan mediasi yang melibatkan pihak ketiga sebagai pihak yang netral untuk menyelesaikan sengketa para pihak secara damai. Oleh karenanya, konsiliasi dan mediasi sulit untuk dibedakan. Istilahnya sering kali digunakan secara bergantian.

Namun menurut Beherens, ada perbedaan mencolok di antara keduanya, yaitu konsiliasi lebih formal dan mediasi sebaliknya. ${ }^{61}$ Lain halnya dengan Munir Fuady yang menyatakan bahwa perbedaan antara mediator dan konsiliasi adalah adanya kewenangan dari mediasi untuk juga mengusulkan penyelesaian sengketa, dimana hal ini secara teoretis tidak dimiliki oleh seorang konsiliator. ${ }^{62}$

Namun demikian, sama seperti mediasi, dalam proses konsiliasi (penyelesaian sengketa transaksi bisnis internasional yang menggunakan e-commerce), juga tidak memiliki kewenangan untuk memberikan putusan terhadap sengketa tersebut. Hal inilah yang membedakan keduanya dengan arbitrase, yang memiliki kewenangan memberikan putusan yang mengikat terhadap sengketa para pihak tersebut. ${ }^{63}$

Dalam pelaksanaannya, konsiliasi dapat diselesaikan oleh seorang individu atau suatu badan yang disebut dengan badan atau komisi konsiliasi. Komisi konsiliasi ini bisa yang sudah terlembaga atau ad hoc (sementara). Komisi ini berfungsi untuk menetapkan persyaratanpersyaratan penyelesaian yang diterima oleh para pihak. Namun, putusannya tidaklah mengikat para pihak. Contoh komisi konsiliasi yang terlembaga adalah the ICSID Rules of Procedure for Conciliation Proceedings

Yahya Ahmad Zein, Op. cit., hlm. 109.

Ibid.

Khotibul Umam, Cet-1, Penyelesaian Sengketa di Luar Pengadilan, (Yogyakarta: Pustaka Yustisia, 2010), hlm. 11.

Huala Adolf, Op. cit., hlm. 205.

Munir Fuady, Pengantar Hukum Bisnis, (Bandung: PT. Citra Aditya Bakti, 2002), hlm. 315.

Ibid. 
(Conciliation Rules) ${ }^{64}$. Namun dalam prakteknya, penggunaan cara ini kurang populer. ${ }^{65}$

Persidangan suatu komisi konsiliasi biasanya terdiri dari dua tahap, yaitu tahap tertulis dan tahap lisan. Pertama, sengketa (yang diuraikan secara tertulis, d.h.i transaksi bisnis internasional yang menggunakan e-commerce) diserahkan kepada badan konsiliasi. Kemudian, badan ini akan mendengarkan keterangan lisan dari para pihak. Para pihak dapat hadir pada tahap pendengaran tersebut, tapi bisa juga diwakilkan oleh kuasanya. ${ }^{66}$ Berdasarkan fakta-fakta yang diperolehnya tersebut, maka konsiliator (pihak ketiga yang netral dalam penyelesaian sengketa para pihak) atau badan konsiliasi akan menyerahkan laporannya kepada para pihak disertai dengan kesimpulan dan usulan-usulan penyelesaian sengketanya. Sekali lagi, usulan ini tidaklah mengikat. Oleh karena itu, diterima tidaknya usulan tersebut bergantung sepenuhnya kepada para pihak. ${ }^{67}$

Tabel 2. Kelebihan dan Kelemahan Model Penyelesaian Sengketa Transaksi Bisnis Internasional yang Menggunakan E-Commerce

\begin{tabular}{|c|c|c|c|}
\hline No. & $\begin{array}{c}\text { Sistem } \\
\text { Penyelesaian } \\
\text { Sengketa }\end{array}$ & Kelebihan & Kelemahan \\
\hline 1. & Badan Pengadilan & $\begin{array}{l}\text { - Menerapkan norma publik } \\
\text { - Ada precedent } \\
\text { - Defference effect } \\
\text { - Keseragaman } \\
\text { - Independensi } \\
\text { - Putusan mengikat } \\
\text { - Keterbukaan } \\
\text { - Dapat dieksekusi } \\
\text { - Melembaga } \\
\text { - Pendanaan secara publik }\end{array}$ & $\begin{array}{l}\text { - Mahal } \\
\text { - Memakai lawyer, sehingga mereka tidak } \\
\text { - } \text { Keputusantrol } \\
\text { - } \text { Tidak ahli substansi (d.h.i transaksi bisnis } \\
\text { internasional yang menggunakan e-commerce) } \\
\text { - Menunda-nunda } \\
\text { - Banyak butuh waktu (proses persidangan yang } \\
\text { lama) } \\
\text { - Masalah diredefinisi dan dipersempit } \\
\text { - Ganti rugi terbatas } \\
\text { - Tidak ada kompromi } \\
\text { - Polarisasi cenderung bermusuhan }\end{array}$ \\
\hline
\end{tabular}

64 Dalam sejarahnya, komisi ini merupakan badan yang dibentuk oleh Bank Dunia untuk menyelesaikan sengketasengketa penanaman modal asing.

65 Hal tersebut dapat dilihat dari efektivitas kinerja ICSID dalam menangani setiap sengketa yang dihadapkan kepadanya. Sejak berdiri pada tahun 1966, badan konsiliasi ICSID hanya menerima dua kasus. Kasus pertama diterima pada 5 Oktober 1982. Namun, sebelum badan konsiliasi terbentuk, para pihak sepakat mengakhiri persengketaannya. Kasus kedua, yaitu Tesoro Petroleum Corp. vs Government of Trinindad and Tobago yang diterima pada tahun 1983. Kasus ini berhasil diselesaikan pada tahun 1985, setelah para pihak sepakat untuk menerima usulan-usulan yang diberikan oleh konsiliator. Melihat rentang waktu berdirinya hingga dewasa ini, maka peran ICSID dalam menangani sengketa bisnis internasional tidaklah efektif bahkan dapat dikatakan gagal. Periksa, Huala Adolf, Op. cit., hlm. 205-206.

66 Ibid., hlm. 205.

67 Ibid. 


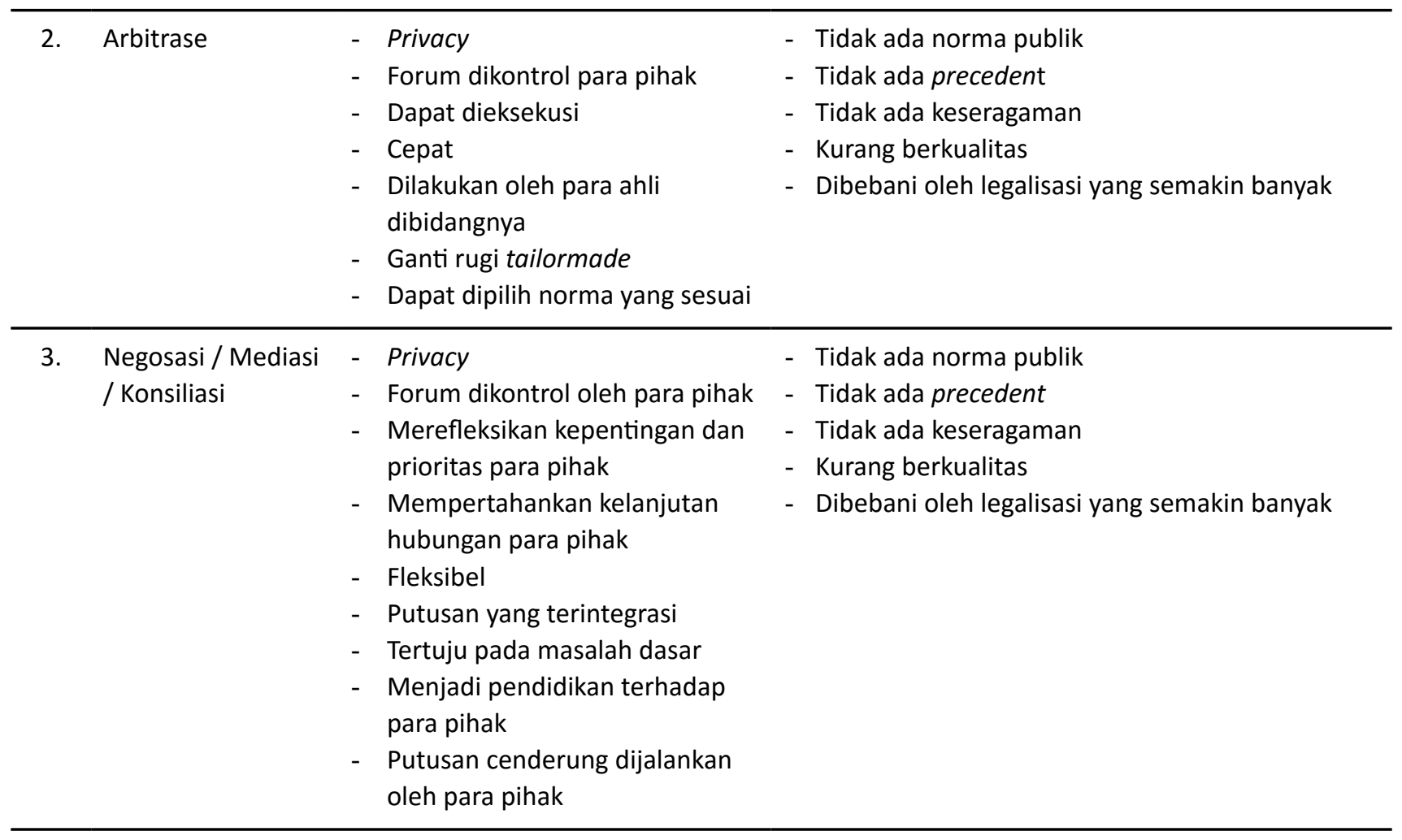

\section{Penutup}

Berdasarkan uraian di atas, maka dapat disimpulkan bahwa forum yang berwenang dalam penyelesaian sengketa transaksi bisnis internasional yang menggunakan e-commerce adalah forum yang dipilih atas dasar kesepakatan para pihak (choice of forum) dalam kontrak elektronik internasional yang mereka buat. Pilihan forum ini dapat dilakukan secara tegas, maupun secara diam-diam. Adanya prinsip pilihan forum ini diatur dalam ketentuan Principle 2.1 bagian (1) dari PTCP (tentang Jurisdiction over Parties). Bilamana para pihak tidak menentukan pilihan forum dalam kontrak elektronik internasional yang dibuatnya adalah mengacu pada forum dari negara penjual atas dasar ketentuan yang termaktub dalam asas-asas Hukum Perdata Internasional. Hal ini dikarenakan, penjual merupakan pihak yang memiliki prestasi paling karakteristik dibanding pihak lainnya. Penentuan tersebut didasarkan atas Substansial Connection Theory sebagaimana yang dikemukakan dalam Principle 2.1 bagian (2) dari PTCP (tentang Jurisdiction over Parties).

Adapun terkait dengan model penyelesaian sengketa tersebut dimungkinkan untuk digunakannya dua mekanisme, yaitu jalur litigasi dan non litigasi. Mekanisme litigasi berupa jalur penyelesaian sengketa melalui pengadilan. Sedangkan non litigasi berupa jalur penyelesaian sengketa melalui arbitrase, negosiasi, mediasi, dan konsiliasi.

Dari beberapa temuan di atas maka direkomendasikan terhadap para pihak memuat suatu pilihan forum (choice of forum) dalam kontrak elektronik internasional terkait dengan penyelesaian sengketa. Hal tersebut ditujukan untuk menjamin kepastian hukum di antara para pihak. Serta untuk menghindari berlakunya asasasas HPI yang dapat menimbulkan penggunaan 
forum yang sama sekali tidak dikehendaki oleh para pihak.

Mengingat transaksi bisnis internasional yang menggunakan e-commerce merupakan bagian dari kegiatan dunia bisnis, yang tentunya menghendaki suatu penyelesaian sengketa yang cepat, rahasia, dan murah, maka sebaiknya para pihak memilih forum arbitrase sebagai model penyelesaian sengekta tersebut. Diharapkan dengan adanya penggunaan forum arbitrase ini dapat menghasilkan keputusan yang cepat, damai, menguntungkan para pihak, dan tentunya dapat dilakukan eksekusi (executable).

Kemudian terhadap transaksi bisnis internasional yang menggunakan e-commerce lintas negara, maka para pihak hendaknya dapat mempertimbangkan dan menyelaraskan relevansi antara kepentingan hukum yang berlaku dan forum yang berwenang. Dengan tujuan untuk menghindari pertentangan substansial formil dan materil di antara keduanya. Dan terhadap regulasi yang ada perlu dibentuknya suatu norma konkritual positivis berupa Peraturan Pemerintah tentang penyelesaian sengketa transaksi e-commerce yang lebih komprehensif, baik itu dalam hal prosedural formil, ataupun materil, yang merupakan pelaksana dari Pasal 18 UndangUndang No. 11 Tahun 2008 tentang Informasi dan Transaksi Elektronik.

\section{Daftar Pustaka}

\section{Buku}

Ade Maman Suherman, Aspek Hukum dalam Ekonomi Global, (Jakarta: Ghalia Indonesia, 2001)

Ahmad M. Ramli, Cet-2, Cyberlaw dan HAKI dalam Sistem Hukum Indonesia, (Bandung: PT. Refika Aditama, 2006)

Ahmad Romsan, Teknik Penyelesaian Sengketa di Luar Pengadilan: Negosiasi, Mediasi, dan Arbitrase, Cet-2, (Inderalaya: Bagian Hukum
Internasional, Fakultas Hukum Universitas Sriwijaya, 2008)

Bayu Seto, Buku ke-1 (Edisi Keempat), Dasar-Dasar Hukum Perdata Internasional, (Bandung: PT. Citra Aditya Bakti, 2006)

Didik M. Arief Mansur dan Elisatiris Gultom, Cyber Law: Aspek Hukum Teknologi Informasi, Cet-2, (Bandung: PT. Refika Aditama)

Gunawan Widjaja dan Ahmad Yani, Hukum Arbitrase, (Jakarta: PT. RajaGrafindo Persada, 2000)

Huala Adolf, Hukum Perdagangan Internasional, (Jakarta: PT. RajaGrafindo Persada, 2005)

Khotibul Umam, Penyelesaian Sengketa di Luar Pengadilan, Cet-1, (Yogyakarta: Pustaka Yustisia, 2010)

M. Arsyad Sanusi, Hukum Teknologi Informasi, Cet-3, (Tim KemasBuku, 2005)

Mieke Komar Kantaatmadja et. al, Cyberlaw: Suatu Pengantar (Seri Dasar Hukum Ekonomi), (Bandung: ELIPS II, 2002)

Munir Fuady, Pengantar Hukum Bisnis, (Bandung: PT. Citra Aditya Bakti, 2002)

Munir Fuady, Buku Ke-2, Hukum Kontrak: Dari Sudut Pandang Hukum Bisnis, (Bandung: PT. Citra Aditya Bakti, 2003)

Munir Fuady, Arbitrase Nasional: Alternatif Penyelesaian Sengekta Bisnis, (Bandung: PT. Citra Aditya Bakti, 2003)

Niniek Suparni, Cyberspace: Problematika dan Aspek Pengaturannya, (Jakarta: Penerbit Sinar Grafika, 2009)

Peter Mahmud Marzuki, Penelitian Hukum, (Jakarta: Kencana Prenada Media Group, 2005)

R. Subekti dan R. Tjitrosudibio, Kitab UndangUndang Hukum Perdata, Jakarta: Pradnya Paramita, 1983)

Rachmadi Usman, Hukum Arbitrase Nasional, (Jakarta: Grasindo, 2002)

Rachmadi Usman, Pilihan Penyelesaian Sengketa di Luar Pengadilan, (Bandung: PT. Citra Aditya Bakti, 2003)

Riyeke Ustadianto, Framework E-Commerce, Cet-1, (Yogyakarta: Penerbit Andi, 2001)

Saut P. Panjaitan, Dasar-Dasar Ilmu Hukum: Asas, Pengertian, dan Sistematika, (Palembang, Penerbit Universitas Sriwijaya, 1998)

Syahrin, M.A., 2017. Konsep Teoretis Penyelesaian Sengketa Hukum E-Commerce. Mahara Publishing

Syahrin, M.A., 2017. E-Commerce: Pilihan Hukum dan Pilihan Forum. Mahara Publishing 
Syahrizal Abbas, Mediasi: Dalam Perspektif Hukum Syariah, Hukum Adat, dan Hukum Nasional, (Jakarta: Prenada Media Group, 2009)

Sutan Remy Sjahdenini, Kebebasan Berkontrak dan Perlindungan Hukum yang Seimbang bagi Para Pihak dalam Perjanjian Kredit Bank di Indonesia, (Jakarta: Institut Bankir Indonesia, 1993)

SP Hariningsih, Teknologi Informasi, (Jakarta: Graha Ilmu, 2005)

Subekti, Hukum Perjanjian, Cet-16, (Jakarta: PT. Intermasa, 1996)

Yahya Ahmad Zein, Kontrak Elektronik dan Penyelesaian Sengketa Bisnis E-Commerce: Dalam Transaksi Nasional dan Internasional, (Bandung: Mandar Maju, 2009)

Yudha Bhakti Ardhiswastra, Penafsiran dan Konstruksi Hukum, (Bandung: Alumni, 2008)

\section{Makalah/Artikel/Prosiding/Hasil Penelitian}

Fahroy, C.A. and Syahrin, M.A., 2016. Antara Batas Imajiner dan Kedaulatan Negara. Imigrasi di Batas Imajiner, Jakarta: Kantor Imigrasi Kelas I Khusus Soekarno Hatta

Katsh, E., Rifkin, J. and Gaitenby, A., 1999. E-commerce, E-disputes, and E-dispute resolution: in the shadow of eBay law. Ohio St. J. on Disp. Resol., 15

Katsh, E., 2001. Online dispute resolution: Some lessons from the e-commerce revolution. $\mathrm{N}$. $\mathrm{Ky}$. L. Rev., 28

Martin, M.S., 2002. Keep it online: The Hague Convention and the need for online alternative dispute resolution in international business-toconsumer e-commerce. BU Int'I LJ, 20

Nadler, J., 2001. Electronically-mediated dispute resolution and e-commerce. Negotiation Journal, 17(4)
Panagariya, A., 2000. E-commerce, WTO and developing countries. The World Economy, 23(8)

Syahrin, M.A., 2017. The Implementation of NonRefoulement Principle to the Asylum Seekers and Refugees in Indonesia. Sriwijaya Law Review, 1(2), pp.168-178

Syahrin, M.A., 2017. Refleksi Teoretik E-Contract: Hukum yang Berlaku dalam Sengketa Transaksi Bisnis Internasional yang Menggunakan E-Commerce. Lex Librum: Jurnal IImu Hukum, 3(2)

Syahrin, M.A., 2018. Menakar Kedaulatan Negara dalam Perspektif Keimigrasian. Jurnal Penelitian Hukum De Jure, 18(1), pp.43-57

Syahrin, M.A., 2017. Actio Pauliana: Konsep Hukum dan Problematikanya. Lex Librum: Jurnal IImu Hukum, 4(1)

\section{Internet}

https://www.idntimes.com/business/economy/ yoshi/pertumbuhan-e-commerce-indonesia-1, (diakses 3 Juli 2018)

\section{Peraturan}

Kitab Undang-Undang Hukum Perdata (Burgerlijk Wetboek)

Undang-Undang Nomor 11 Tahun 2008 tentang Informasi dan Transaksi Elektronik

The Brussels Convention

The New York Convention

The UNCITRAL Arbitration Rules

The EC Council Regulation on Jurisdiction and the Recognition and Enforcement of Judgments in Civil and Commercial Matter 